\title{
Drying in Brazil Nut Processing as Tool for Prevention of Contamination by Aflatoxins
}

\author{
Ariane M. Kluczkovski (Corresponding Author), Allyne C. P. da Silva, Janaína Barroncas, \\ Jacqueline Lima, Henrique Pereira, Pedro Mariosa, Maria Luana Vinhote \\ Federal University of Amazonas, Brazil
}

Received: June 10, 2020

Accepted: June 19, 2020

Published: July 20, 2020

doi:10.5296/jas.v8i4.17387

URL: https://doi.org/10.5296/jas.v8i4.17387

\begin{abstract}
Drying is fundamental in the processing of Brazil nuts to prevent contamination by aflatoxins which are produced by fungi, as well as to extend the shelf life of the product. The binomial time/temperature is applied to guarantee the efficiency of drying stages. In this context, the objective of this study was to evaluate the parameters of moisture content $(m c)$ and water activity $(A w)$ in processed and unprocessed nuts obtained from a processing plant in the Amazonas state, Brazil, during the harvests of 2019 and 2020. Differences were observed regarding $A w$ between the harvests, and in processed and unprocessed samples. However, for $m c$, no differences between years or interaction between factors were observed. Processed samples from 2019 and 2020 showed a significant reduction in moisture content when compared to unprocessed samples and this may be because some modernization occurred in the drying process and raw material was stored under better conditions. We therefore conclude that the time/temperature binomial has a direct impact on product safety and should be applied from the moment of collection of raw material until the industrial process begins to guarantee economic maintenance of the production chain.
\end{abstract}

Keywords: Bertholletia excelsa, good practices, moisture content, water activity

\section{Introduction}

In the tropical forest region, Brazil nuts (Bertholletia excelsa) are the principal non-timber product, and they are intrinsically linked to the culture of traditional Amazonian populations, since nuts have been used as a source of food and income for many generations (Bertwell et al., 2018). In this context, it is essential to protect seeds against toxic agents produced by fungi, such as aflatoxins (AFL); carcinogens that contaminate food. In Brazil nuts, the genus Aspergillus is often isolated and related to the production of AFL (Taniwaki et al., 2018; Ismail et al., 2018). AFL are secondary metabolites which are carcinogenic to humans and animals (IARC, 2016). Since the turn of the last century, the occurrence of AFL in Brazil nuts has 
greatly impacted commercialization, and they have been reported in samples sold in several countries, including the United States, Japan, Sweden, and Brazil (Taniwaki et al., 2019). In an effort to prevent contamination and, as a result, exposure of the population to this poisonous carcinogen, studies have tested the application of physical or chemical methods to prevent its occurrence (Oliveira et al., 2020; Ribeiro et al., 2020). Although Brazil nuts are highly nutritious with proteins and antioxidants, and generate clinical benefits to the human metabolism (Reis et al., 2019; Rusu et al., 2019), due to the artisanal mode of extraction of the nuts in the forest and inadequate temperatures during storage and processing, some fungi can produce AFL. Several studies mention that environmental conditions, such as relative humidity (RH) over $70 \%$ and temperatures over $30{ }^{\circ} \mathrm{C}$, as well as climate change can affect the production of AFL and therefore food quality. Since the Bertholletia excelsa grows under these conditions, this can also be observed for Brazil nuts (Funatsu et al., 2019; Medina et al, 2017). In the production chain, there are several drying stages that represent a challenge due to the different sizes of the nuts, which may be classified as either tiny, medium, large or extra-large (Mello \& Scussel, 2007). Dehydration is used to control the product's intrinsic characteristics, such as moisture content $(m c)$ and water activity $(A w)$, in addition to the product's sensory quality (Silva et al., 2016) and thus extend shelf life. Silva and Marsaioli (2004) reported that the Brazil nut in natura, presented $A w$ in the range of 0.79-0.91, that is, before the drying stages. This range would indicate the need for intervention and the implementation of improvements in the technological safety of the raw material, since at the international level the recommended $A w$ content level in order to prevent the formation of AFL in tree nuts is $A w<0.70$ (CAC, 2010). In the forest, quick drying is not always possible, because the Brazil nut crops in the Amazon region are harvested during the rainy season. In addition, due to the location of the trees, the logistics involved in getting the nuts to the processing plant can be complicated. In the factories where the processing takes place, dehydration occurs in rotary dryers or trays (Pacheco and Martins, 2013) in which the binomial time/temperature is applied to maintain the $m c$ at safe levels in order to meet legal standards and preserve product characteristics. After harvesting, storage conditions can introduce contamination. The nuts, if stored throughout the year, may be a risk to the human health due to close contact with the considerable carcinogenic potential of the AFL. Furthermore, improper storage in open markets implies the risk of contamination of a larger number of people in the urban environment and thus the possibility of increased cases of liver cancer in this population (Lima et al., 2012). In Brazil, the Amazonas state has several small agro-industries with compact production structures, in relation to the processing plants. There are five cooperatives, located in different mesoregions of the Brazilian Amazon, such as the middle Rio Negro, Alto Solimões, Purus and Madeira. In 2017, they are responsible for producing 1,269 tons of nuts, of these 1,009 tons are sold in natura and another 260 tons undergo dehydration processes (IDAM, 2017). In this context, an experimental study was carried out at the premises of one of these cooperatives with the objective of validating the dehydration process utilized in two harvests (2019 and 2020), using the variables for water activity and moisture content in relation to the levels of AFL contamination in Brazil nuts. 


\section{1) Macrothink}

\section{Method}

\subsection{Sampling}

Samples $(n=60)$ were collected at a Brazil nut processing facility in the Amazonas state, Brazil during the harvests of 2019 and 2020. The samples were classified as follows: (a) undried (raw material, collected shortly after arrival at the facility or at the supplier's small-scale facilities) and (b) dried (at the end of drying processes). The production flowchart is presented in Figure 1.

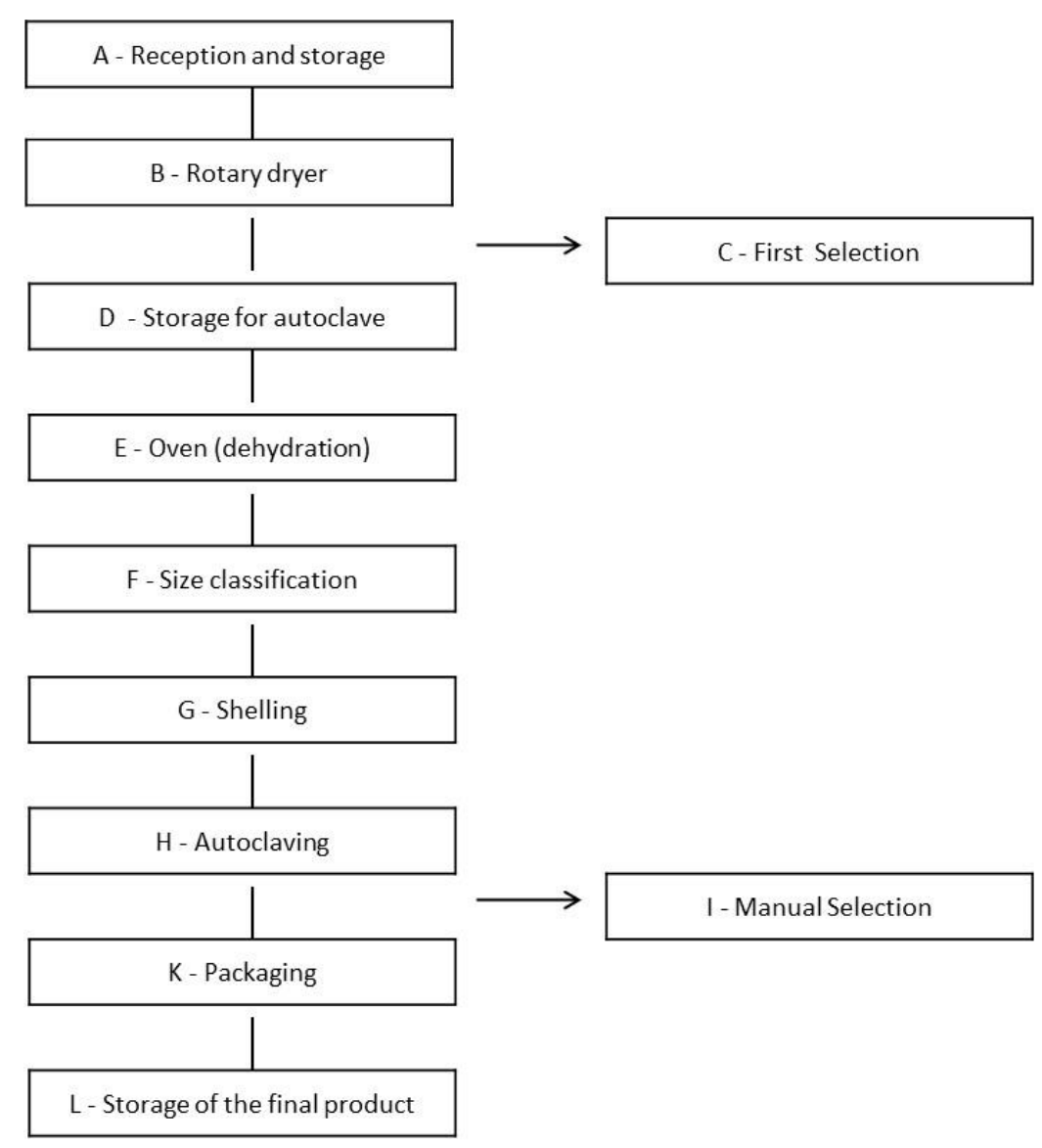

Figure 1. Flow chart of Brazil nut processing at a cooperative in the Brazilian Amazon

\subsection{Moisture Content ( $\mathrm{mc})$ and Water Activity (Aw)}

Moisture content $(m c)$, as determined by AOAC (2016), was obtained by means of an electronic moisture balance (SHIMADZU, MOC-120H®, Kyoto, Japan) and an infrared dryer, by drying about $1 \mathrm{~g}$ of the sample at a temperature of $105^{\circ} \mathrm{C}$ until loss of all moisture. All analyses were performed in duplicate and the results were expressed as mean and standard deviation. The water activity $(A w)$ was verified with a bench top water activity meter (AquaLab series 4TE by DECAGON) at room temperature $\left(25^{\circ} \mathrm{C}\right)$ and used the dew point method. All analyses were performed in duplicate and the results expressed as mean and standard deviation. 


\subsection{Aflatoxin Quantification (AFL)}

AFL levels were quantified by liquid chromatography (HPLC), according to the AOAC Official Method (AOAC, 2016). In a $50 \mathrm{~g}$ sample, the AFLs were extracted with $100 \mathrm{~mL}$ of acetonitrile:water solution $(90: 10 \mathrm{v} / \mathrm{v})$ and shaken at a high speed for 5 minutes with subsequent filtering using filter paper. Then, $3 \mathrm{~mL}$ of the filtrate were transferred to a $10 \mathrm{~mL}$ culture tube with application by a MYCOSEP 226 (Romer labs) cleaning column for extract purification. The resulting solutions were applied and quantified in HPLC with mobile phase acetonitrile, methanol, and ultra-pure water (1:1:4), Waters X-Terra column, 150 x $4.6 \mathrm{~mm}$, flow of $1.0 \mathrm{~mL} \cdot \mathrm{min}^{-1}$ eluting in isocratic mode, with fluorescence detector: $\lambda$ excitation- 360 $\mathrm{nm}$, and $\lambda$ emission- $440 \mathrm{~nm}$; volume of injection of $50 \mu \mathrm{L}$; race time of 20 minutes. Three pools of AFL standards $B_{1}, B_{2}, G_{1}$, and $G_{2}$ (Sigma Aldrich) were used. The Limit of Detection (LOD) and Limit of Quantification (LOQ) for each toxin ( $\mathrm{AFB} 1 / \mathrm{AFB}_{2} / \mathrm{AFG}_{1} / \mathrm{AFG}_{2}$ ) were $0.136 / 0.136 / 0.250 / 0.250$ and $0.410 / 0.410 / 0.750 / 0.750 \mu \mathrm{g} / \mathrm{kg}$, respectively. The LOD method was defined by 3 times the signal/noise ratio and LOQ by 6 times the signal/noise. Five points were used to build an analytical curve to obtain the correlation coefficient $(R)$ values for LOD and LOQ. Each point corresponded to a mean of five injections of each extract. The recoveries for each $\mathrm{AFL}\left(\mathrm{AFB}_{1}, \mathrm{AFB}_{2}, \mathrm{AFG}_{1}, \mathrm{AFG}_{2}\right)$ were 94.5, 73.5, 97.8, and 99.1\%, respectively.

\subsection{Statistical Analysis}

A two-way ANOVA analysis was performed using the software PAST (version 4.02) by Hammer et al. (2001) and factors (group independent variables) were year (2019 or 2020) and processing (Yes or No). We investigated the contributions that each of the factors make individually to the response in terms of $A w$ and $m c$. The two-way complete model allowed the interaction of the two factors.

\section{Results and Discussion}

In general, the purpose of drying is to reduce the $A w$ of the nuts and effectively control fungal growth and AFL. The results of the analysis are presented in Table 1, and show undetected levels (N.d) of AFL in dried samples and low levels of AFL in undried samples from both harvest years. It was observed that the samples met the acceptable limit for shelled Brazil nuts $<10 \mathrm{ug} / \mathrm{kg}$ for total AFL according to European legislation (EU, 2011).

Table 1. Variables of Brazil nut drying process: aflatoxin, water activity and moisture content

\begin{tabular}{llccc}
\hline Harvests & Samples & AFL Total \pm SD (Range) & $\mathrm{Aw}^{2}$ & $m c^{3}$ \\
\hline 2019 & Non-dried & $0.59 \pm 1.17\left(\mathrm{~N}^{2} \mathrm{~d}^{4}-5.50\right)$ & $0.88-0.99$ & $6.91-32.56$ \\
& Dried & N.d & $0.36-0.53$ & $2.48-3.36$ \\
2020 & Non-Dried & $0.77 \pm 1.14(\mathrm{~N} . d-5.03)$ & $0.98-0.99$ & $17.92-29.14$ \\
& Dried & N.d & $0.23-0.29$ & $0.25-0.42$ \\
\hline
\end{tabular}

${ }^{1}$ Total AFL \pm Standard Deviation; ${ }^{2}$ Water Activity; ${ }^{3}$ Moisture content $\% ;{ }^{4}$ Not Detected in Limit of Detection. 


\section{Macrothink}

Journal of Agricultural Studies

ISSN 2166-0379

2020, Vol. 8, No. 4

Table 1 also shows the levels of $A w$ in undried samples $>0.7$, which is the maximum level recommended by the European Union (CAC, 2010). The dried samples provided $A w$ levels low enough to keep the $m c$ at less than $5 \%$ (level of $m c$ adopted by the facility as a control measure). According to our findings, which are described in Table 2, there were differences between harvests and processed and unprocessed samples for $A w$.

Table 2. Two-way ANOVA for Water Activity (Aw)

\begin{tabular}{lccccc} 
& Sum of sqrs & df & Mean square & F & p (same) \\
\cline { 2 - 6 } Harvest: & 0.00532324 & 1 & 0.005323 & 6.364 & 0.01451 \\
Process: & 3.10601 & 1 & 3.10601 & 3713 & $6.96 \mathrm{E}-53$ \\
Interaction: & 0.107642 & 1 & 0.107642 & 128.7 & $3.89 \mathrm{E}-16$ \\
Within: & 0.0468395 & 56 & 0.000836 & & \\
Total: & 3.26581 & 59 & & & \\
\hline
\end{tabular}

The interaction presented significant results and led us to examine both main effects separately (Figures 2a and 2b). In 2020, there was a great reduction in $A w$ levels in the processed materials, compared to the samples from 2019.

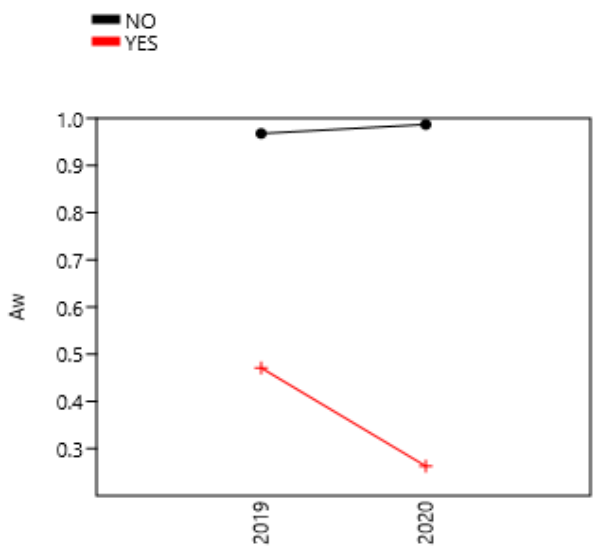

Fig 2a. Interaction by harvest

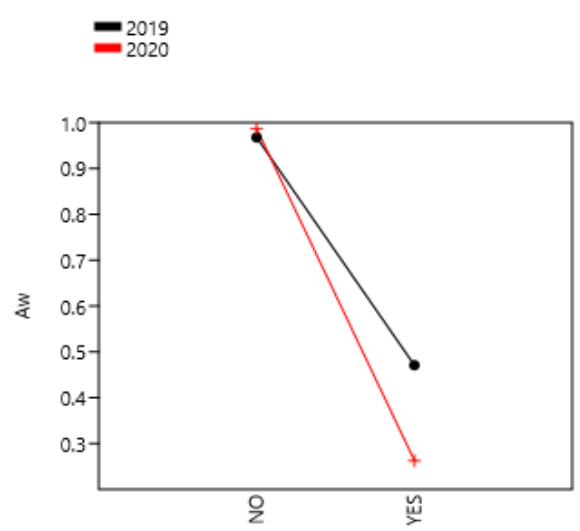

Fig 2b. Interaction of Brazil nut samples (dried and undried)

Figure 2. Interaction of Brazil nut samples for Aw

Regarding $m c$, no differences between harvests or interaction between factors were observed (Table 3). 
Table 3. Two-way ANOVA for moisture content $(m c)$

\begin{tabular}{cccccc} 
& Sum of sqrs & df & Mean square & F & p (same) \\
\cline { 2 - 6 } Harvest: & 0.00445223 & 1 & 0.004452 & 1.398 & 0.242 \\
Process: & 0.296024 & 1 & 0.296024 & 92.98 & $1.68 \mathrm{E}-13$ \\
Interaction: & 0.000663202 & 1 & 0.000663 & 0.2083 & 0.6499 \\
Within: & 0.178289 & 56 & 0.003184 & & \\
Total: & 0.479428 & 59 & & & \\
\hline
\end{tabular}

Processed samples from 2019 and 2020 showed a significant reduction in $m c$ compared to unprocessed samples (Figures $3 \mathrm{a}$ and $3 \mathrm{~b}$ ).

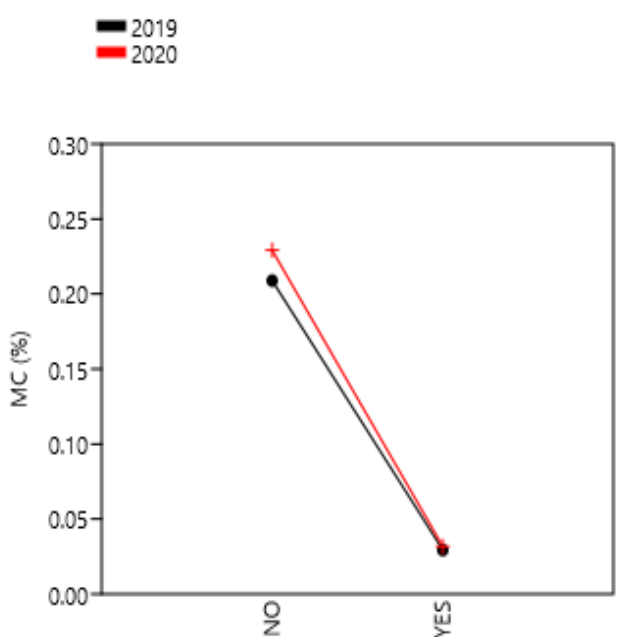

Figure 3a. Mc in different samples (dried and undried)

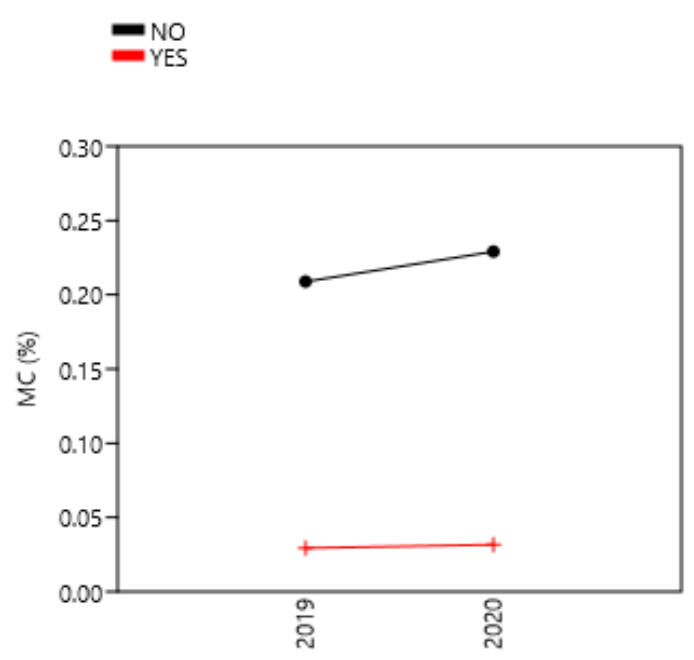

Figure 3 b.Mc in different harvests

Figure 3. Moisture content interaction

Other studies have evaluated the $A w$ content at time of harvest in the forest, though the drying conditions are artisanal and without temperature control. In data reported by Leite et al. (2014), in which Brazil nut pod (fruit) samples were tested at the time when the pods were on the forest floor, AFL levels were low during the whole study period, which suggests that adverse forest conditions were not the main factor in stimulating the production of AFL. At the factory storage stage, silos and drying kilns have temperature and humidity measurement 
systems. Aeration was a system adopted in the silos for nut storage in the study by Costa et al. (2017) and samples were compared to the traditional method. Costa et al. (2017) found that this system reduced the moisture content of the nuts by $78.2 \%$ after 150 days, however this reduction was not fast enough to avoid contamination completely, and potentially produced filamentous AFL fungi. The $A w$ of nuts ranged from 0.99-0.52, showing a trend of reduction over storage time. According to Botelho et al. (2019), to reduce the risk of fungal development, the Brazil nut must be stored at temperatures $<55{ }^{\circ} \mathrm{C}$ and the $m c$ content must be $<8.2 \%$. In our study, at the plant where the dried samples were collected, the average drying temperature in the oven at the end of the process is $70{ }^{\circ} \mathrm{C}$, but the storage of the finished product is between $25-30^{\circ} \mathrm{C}$. Therefore, it is essential that the study uses the study of Brazil nut sorption isotherms as tested by Chisté et al. (2007), in which it was observed that to ensure microbiological stability $(A w<0.6)$, the nut moisture content should not be greater than $1.62 \mathrm{~g} \%$. This limit on the moisture content of the finished product is a variable that also influences sensory aspects of the product, such as crispness, so each company finds its own acceptable range of moisture content. Considering that the recommendation for each dehydration system in the processing plant is to use a safe sorption system with $A w<0.7$, we recommend that the system of several drying steps with rotary or tray dryers be monitored as control points for product safety. In this context, we indicate the need for the hazard analysis and critical control points (HACCP) system to analyze all possible steps in which control measures are applied, not just drying. Arisseto-Bragotto (2017) cites the HAACP system as the most important quality management tool used in the food industry in Brazil due to prevention of risks to human health, and prevention of adulteration of foodstuffs via risk control measures.

We also observed that there was no positive sample for AFL at an $A w<0.9$ level, as shown in Figure 4. This can be explained by the Good Management Practices (GMP) being applied to the raw material by suppliers, in addition to care in storage and transportation. GMP are defined by Brazilian legislation as "basic practices for members of the Brazil nut production chain, aiming to meet the principles of Good Agricultural Practices and Standardized Procedures for Operational Hygiene (Brazil, 2011). As examples of this type of management, selection of the nuts and drying before storage; artificial drying (solar or ovens) should begin soon after harvest and progress as rapidly as feasible, storage under atmospheres controlled for RH are noteworthy. Duchelle et al. (2013) cite the "best management practices" as: (1) preharvest practices; (2) silvicultural practices; and (3) harvest and postharvest practices, such as nut drying. These actions have already been cited as possible tools for the prevention of AFL in undetected results and have been presented by other authors. Baquião et al. (2013) analyzed fresh Brazil nut samples from different locations and found undetected samples of AFL. The authors' results, are in accordance with the findings of other investigators who analyzed samples from the Amazon region. In their study, the $A w$ of stored samples did not reach 0.80 , a value which favors fungal growth but prevents the production of AFL. In the industry, the extraction of the shells and screening for nuts that have been visibly deteriorated by fungi also may have contributed to the absence of AFL in the stored nuts. In processed (dry) nuts that were exported, we can cite the results of Cunha et al. (2018) who analyzed Brazil nuts in Porto (Portugal) and 2 samples were free of AFL contamination when analyzed 
by LCMS-MS. Essawet et al. (2017) analyzed nut samples in Lybia, and $40 \%$ of the samples were positive samples for AFL. These two studies suggest that, despite the improvement in the factory of origin, dehydration is efficient in making the finished product safe until it reaches the consumers on other continents, though the conditions of transport and storage may offer conditions for new fungal contamination with the production of AFL. Tai et al. (2020) suggest that integrating various post-harvest methods with synergistic functions may be more efficient for the control of A. flavus growth and AFL production, although individual environmental factors alone have an impact.

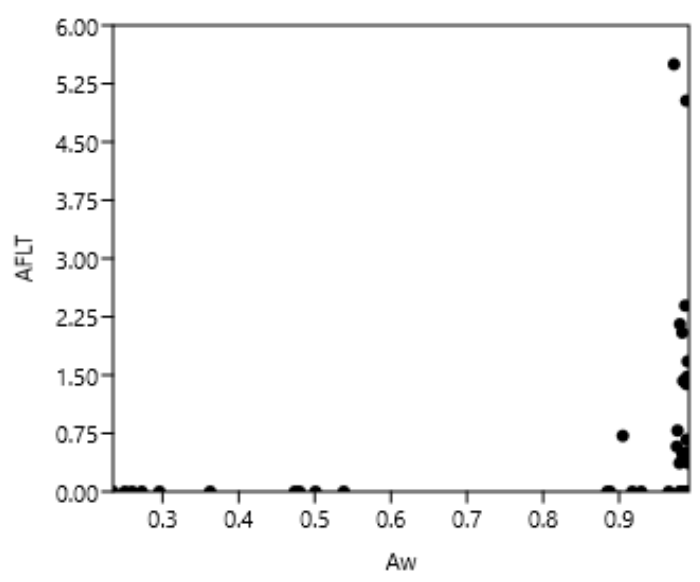

Figure 4. Aw in AFL positive samples

After the dehydration steps, other strategies can be applied to maintain products at safe levels, such as $\mathrm{CO}_{2}$ (Mahbobinejhad et al., 2019) and ozone application (Oliveira et al., 2020). Considering the obtained data, we can observe that the improvement of the process for the two harvests guaranteed that the variables $A w$ and $m c$ helped maintain the safety of the nut against AFL. This has a direct impact since it contributes to the socio-economic well-being of the cooperative and its collaborators, since the activity guarantees the economic sustenance for the many families that depend on it. Accordingly, the markets value of the product supplied by the cooperatives is slightly higher than when available in other modes of commercialization, which are based on intermediation (Souza-Silva, 2019). This is because the context of social benefit and environmental protection of the forest adds value to the product.

\section{Conclusion}

The objective of the study was fulfilled since the two harvests showed the impact of dehydration regarding $A w$ and $m c$ in AFL prevention in Brazil nuts. Processed samples from the 2019 and 2020 harvests showed a significant reduction in $m c$ content compared to 
unprocessed samples and this may be explained by some modernization in drying, and better storage conditions of raw material. We conclude that the time/temperature binomial has a direct impact on product safety and should be applied since the moment of the collection of raw material until the industrial process begins for economic maintenance of the production chain and this must be adopted in all traditional communities.

\section{Acknowledgments}

To FAPEAM- Fundação de Amparo à Pesquisa do Amazonas

\section{References}

AOAC - Association of Official Analytical Chemists (2016) Official methods of analysis, 20th edition. AOAC International, Gaithersburg, MD, USA

Arisseto-Bragotto, A. P., Feltes, M. M. C., \& Block, J. M. (2017). Food quality and safety progress in the Brazilian food and beverage industry: chemical hazards. Food Quality and Safety, 1(2), 117-129. https://doi.org/10.1093/fqsafe/fyx009

Baquião, A. C., Oliveira, M. M. M., Reis, T. A., Zorzete, P., Atayde, D. D., \& Corrêa, B. (2013). Monitoring and Determination of Fungi and Mycotoxins in Stored Brazil Nuts. $\begin{array}{llll}\text { Journal of Food } & \text { Protection, } & \text { 76(8), }\end{array}$ https://doi.org/10.4315/0362-028X.JFP-13-005

Bertwell, T. D., Kainer, K. A., Cropper, W. P., Staudhammer, C. L., \& Wadt, L. H. O. (2017). Are Brazil nut populations threatened by fruit harvest? Biotropica online, 50(1), 50-59. https://doi.org/10.1111/btp.12505

Botelho, F. M., Boschiroli Neto, N. J., Botelho, S. de C. C., Oliveira, G. H. H. de, \& Hauth, M. R. (2019). Sorption isotherms of Brazil nuts. Revista Brasileira de Engenharia Agrícola e Ambiental, 23(10), 776-781. https://doi.org/10.1590/1807-1929/agriambi.v23n10p776-781

BRAZIL. Ministry of Agriculture, Livestock and Supply. Instruction Normative $\mathrm{n}^{\mathbf{0}} 11,22$ march (2010) Criteria and Procedures for the control hygiene and health the Brazil nut and its by products. Diário Oficial da República Federativa do Brasil, Brasília, DF, 23 mar. 2010.

CAC - Codex Alimentarius Commission., (2010) Proposed draft maximum level for total aflatoxins in brazil nuts. ALINORM 10/33/41 Appendix V, 47. Joint FAO/WHO Food Standards Program, FAO, Rome.

Chisté, R. C., Lopes, A. S., \& da Silva Pena, R. (2012). Moisture adsorption isotherm from Brazil-nut (Bertholletia excelsa). Revista Brasileira de Tecnologia, 6(01), 671-679. https://doi.org/10.3895/S1981-36862012000100006

Costa, D. A., Álvares, V. S., Kusdral, J. F., Nogueira, R. M., Maciel, V. T., \& Miquelonil, D. P. (2017). Quality of in-shell Brazil nuts after drying using a pilot natural convection oven in the state of Acre, Brazil. Brazilian Journal of Food Technology, 20, e2015104. https://doi.org/10.1590/1981-6723.10415

Cunha, S. C., Sa, S. V., \& Fernandes, J. O. (2018). Multiple mycotoxin analysis in nut 
products: Occurrence and risk characterization. Food and chemical toxicology, 114, 260-269. https://doi.org/10.1016/j.fct.2018.02.039

Duchelle, A. E., Kainer, K. A., \& Wadt, L. H. (2013). Is certification associated with better forest management and socioeconomic benefits? A comparative analysis of three certification schemes applied to Brazil nuts in Western Amazonia. Society \& Natural Resources, 27(2), 121-139. https://doi.org/10.1080/08941920.2013.840022

EC- European Comission, $2010 . \quad$ Available at: https://eur-lex.europa.eu/legal-content/PT/TXT/PDF/?uri=CELEX:02006R1881-20200401\&f rom $=\mathrm{EN}$

Essawet, N., Abushahma, H., Inbaia, S., Najii, A., \& Amra, H. A. (2017). Natural Incidence of Aflatoxins and Ochratoxin A Nuts Collected from Local Market in Tripoli. International Journal of Current Microbiology and Applied Sciences, 6, 1479-1486. https://doi.org/10.20546/ijcmas.2017.603.170

Funatsu, B. M., Dubreuil, V., Racapé, A., Debortoli, N. S., Nasuti, S., \& Le Tourneau, F. M. (2019). Perceptions of climate and climate change by Amazonian communities. Global Environmental Change, 57, 101923. https://doi.org/10.1016/j.gloenvcha.2019.05.007

Hammer, Ø., Harper, D. A. T., \& Ryan, P. D. (2001). PAST: Paleontological statistics software package for education and data analysis. Palaeontologia Electronica 4(1): 9pp

IARC - International Agency for Research on Cancer (2016) Agents classified by the IARC Monographs, Volumes 1-116. Available online: http://monographs.iarc.fr/ENG/Classification/

IDAM- Instituto de Desenvolvimento Agropecuário e Florestal Sustentável do Estado do Amazonas (2017). Relatório de Atividades 2017. Manaus. 73p.

Ismail, A., Gonçalves, B. L., Neeff, D. V., Ponzilacqua, B., Coppa, C. F. S. C., Hintzschec, H., ... Oliveira, C. A. F. (2018) Aflatoxin in foodstuffs: Occurrence and recent advances in decontamination. Food Res Int, 113, 74-85. https://doi.org/10.1016/j.foodres.2018.06.067

Leite, F. M. N., de Souza, L., de Souza, J. M. L., da C Cartaxo, C. B., de S Álvares, V., \& da Cunha, C. R. (2014). Incidence of Aspergillus flavus, Aspergillus parasiticus and aflatoxins in Brazil nuts in the Amazon forest environment. World Mycotoxin Journal, 7(2), 199-205. https://doi.org/10.3920/WMJ2012.1488

Lima, A. M., Gonçalves, E. C., Andrade, S. S., Barbosa, M. S., Barroso, K. F., de Sousa, M. B., ... Teixeira, F. M. (2012). Critical points of Brazil nuts: a beginning for food safety, quality control and Amazon sustainability. Journal of the Science of Food and Agriculture, 93(4), 735-740. https://doi.org/10.1002/jsfa.5793

Mahbobinejhad, Z., Aminian, H., Ebrahimi, L., \& Vahdati, K. (2019). Reduction of aflatoxin production by exposing Aspergillus flavus to CO2. Journal of Crop Protection, 8(4), 441-448.

Medina, A., Akbar, A., Baazeem, A., Rodriguez, A., \& Magan, N. (2017). Climate change, 
food security and mycotoxins: do we know enough? Fungal Biology Reviews, 31(3), 143-154. https://doi.org/10.1016/j.fbr.2017.04.002

Mello, F. R., Scussel, V. M. (2009). Development of Physical and Optical Methods for In-shell Brazil Nuts Sorting and Aflatoxin Reduction. Journal of Agricultural Science, 1(2). https://doi.org/10.5539/jas.v1n2p3

Oliveira, G. S., da Silva, M. T. S., Dreyer, T. C., Freire, G. M., Orso, G. A. \& Heimann, J. D. P. (2020). Brazilian exports of castanha-do-Pará (Bertholletia excelsa, H.B.K) under the optics of market concentration. BIOFIX Scientific Journal, 5(1), 07-12. https://doi.org/10.5380/biofix.v5i1.66895

Oliveira, J., Alencar, E., Blum, L., Ferreira, W., Botelho, S. C., Racanicci, A., ... Silva, C. (2020). Ozonation of Brazil nuts: Decomposition kinetics, control of Aspergillus flavus and the effect on color and on raw oil quality. LWT - Food Science and Technology, 123, 109106. https://doi.org/10.1016/j.lwt.2020.109106

Pacheco, A. M., \& Martins, M. (2013) Brazil nut sorting for aflatoxin prevention: a comparison between automatic and manual shelling methods. Food and Science Technology, 33, 369-375. https://doi.org/10.1590/S0101-20612013005000042

Reis, T. A., Oliveira, T. D., Baquião, A. C., Gonçalves, S. S., Zorzete, P., \& Correa, B., 2012. Mycobiota and mycotoxins in Brazil nut samples from different states of the Brazilian Amazon region. Int. J. Food Microbiol. https://doi.org/10.1016/j.ijfoodmicro.2012.08.005

Ribeiro, M. S. S., Freitas-Silva, O., Castro, I. M., Teixeira, A., Marques-da-Silva, S. H., Moraes, A. C. S., ... Sousa, C. L. (2020). Efficacy of sodium hypochlorite and peracetic acid against Aspergillus nomius in Brazil nuts. Journal Pre-proof, S0740-0020(20)30038-1. https://doi.org/10.1016/j.fm.2020.103449

Rusu, M. E., Mocan, A., Ferreira, I. C., \& Popa, D. S. (2019). Health Benefits of Nut Consumption in Middle-Aged and Elderly Population. Antioxidants, 8(8), 302. https://doi.org/10.3390/antiox8080302

Silva, A. C., Sarturi, H. J., Dall'Oglio, E. L., Soares, M. A., Sousa, P. T., Vasconcelos, L. G., $\&$ Kuhnen, C. A. (2016). Microwave drying and disinfestation of Brazil nut seeds. Food Control, 70, 119-129. https://doi.org/10.1016/j.foodcont.2016.04.049

Silva, F. A., \& Marsaioli-Junior, A. (2004). Estudo comparativo da conservação de castanha-do-Brasil (Bertholletia excelsa) seca por microondas e convencionalmente. Boletim do Centro de Pesquisa de Processamento de Alimentos, Curitiba, 22(2), 387-404. https://doi.org/10.5380/cep.v22i2.1202

Sousa-Silva, L. D. J., Pinheiro, J. O. C., dos Santos, E. M., da Costa, J. I., \& Meneghetti, G. A. (2019). O cooperativismo como instrumento para a autonomia de comunidades rurais da Amazônia: a experiência dos agricultores extrativistas do municipio de Lábrea, AM. Boletín de la Asociación Internacional de Derecho Cooperativo International Association of 
Cooperative Law Journal, (55), 199-226. https://doi.org/10.18543/baidc-55-2019pp199-226

Tai, B., Chang, J., Liu, Y., \& Xing, F. (2020). Recent progress of the effect of environmental factors on Aspergillus flavus growth and aflatoxins production on foods. Food Quality and Safety, 4(1), 21-28. https://doi.org/10.1093/fqsafe/fyz040

Taniwaki, M. H., Pitt, J. I., Copetti, M. V., Teixeira, A. A., \& Iamanaka, B. T. (2019). Understanding Mycotoxin Contamination Across the Food Chain in Brazil: Challenges and Opportunities. Toxins, 11, 411. https://doi.org/10.3390/toxins11070411

Taniwaki, M. H., Pitt, J., \& Megan, N. (2018). Aspergillus species and mycotoxins: occurrence and importance in major food commodities. Current Opinion in Food Science, 23, 38-43. https://doi.org/10.1016/j.cofs.2018.05.008

\section{Copyright Disclaimer}

Copyright for this article is retained by the author(s), with first publication rights granted to the journal.

This is an open-access article distributed under the terms and conditions of the Creative Commons Attribution license (http://creativecommons.org/licenses/by/4.0/). 